\title{
Role of N-linked glycosylation in the secretion and enzymatic properties of Rhizopus chinensis lipase expressed in Pichia pastoris
}

\author{
Min Yang ${ }^{1}$, Xiao-Wei $\mathrm{Yu}^{1,2^{*}}$, Haiyan Zheng ${ }^{3}$, Chong Sha ${ }^{1}$, Caifeng Zhao ${ }^{3}$, Meiqian Qian ${ }^{3}$ and Yan $\mathbf{X u}^{1,2^{*}}$
}

\begin{abstract}
Background: The methylotrophic yeast, Pichia pastoris, is widely used as a useful experimental tool in protein engineering and production. It is common for proteins expressed in P. pastoris to exhibit N-glycosylation. In recent years, glycosylation studies in $P$. pastoris have attracted increasing attention from scholars. Rhizopus chinensis lipase $(\mathrm{RCL})$ is one of the most important industrial lipases, and it has four potential N-linked glycosylation sites. The aim of the present study was to determine whether RCL undergoes asparagine-linked ( $N$-linked) glycosylation and to examine the role of this modification in RCL expression and function.
\end{abstract}

Results: In this study, we demonstrated that RCL expressed in Pichia pastoris was N-glycosylated at the sites N-14, $\mathrm{N}-48$ and $\mathrm{N}-60$. The majority of the sites $\mathrm{N}-14$ and $\mathrm{N}-60$ were glycosylated, but the glycosylation degree of the site $\mathrm{N}-48$ was only a very small portion. The glycan on N-60 played a key role in the expression and secretion of RCL. RT-PCR results showed that the mRNA level of proRCLCN60Q remained unchanged even though the protein secretion was hampered. Although the N-glycan on N-14 had no effect on the secretion of RCL, this glycan was beneficial for the lipase catalytic activity. On the other hand, the little amount of N-glycan on N-48 had no effect both on the secretion and activity of RCL in P. pastoris. Moreover, the thermostability analysis of RCL revealed that the lipase with more $\mathrm{N}$-glycan was more thermostable.

Conclusions: $\mathrm{RCL}$ was $\mathrm{N}$-glycosylated when expressed in P. pastoris. The N-glycans of $\mathrm{RCL}$ on the different sites had different functions for the secretion and enzymatic properties of the lipase. Our report may also provide theoretical support for the improvement of enzyme expression and stability based on the N-linked glycosylation modification to meet the future needs of the biotechnological industry.

Keywords: N-glycosylation, Pichia pastoris, Rhizopus chinensis lipase, Enzyme activity, Secretion, Thermostability, LC-MS/MS

\section{Background}

Pichia pastoris is a widely used industrial methylotrophic yeast that has been developed as a useful experimental tool in protein engineering and production [1,2]. It is well known that $P$. pastoris can $\mathrm{N}$-glycosylate proteins via mannose oligosaccharide linked to asparagine through two $\mathrm{N}$-acetylglucosamines [3]. Glycosylation is the most common and important form of post-translational

\footnotetext{
* Correspondence: bioyuxw@aliyun.com; yxu@jiangnan.edu.cn

${ }^{1}$ The Key Laboratory of Industrial Biotechnology, Ministry of Education, School of Biotechnology, Jiangnan University, 1800 Lihu Avenue, Wuxi 214122, Jiangsu, China

${ }^{2}$ State Key Laboratory of Food Science and Technology, Jiangnan University, 1800 Lihu Avenue, Wuxi 214122, Jiangsu, China

Full list of author information is available at the end of the article
}

modification [4]. The addition of a large glycan attached to the protein backbone can dramatically alter the structure, and consequently the function of the polypeptide architecture [5]. In recent years, glycosylation studies in $P$. pastoris have attracted increasing attention from scholars. The diverse roles of glycans were implicated in the control of the conformational maturation, activity and stability of glycoproteins [6-9].

Since control over the resulting glycan structural and spatial arrangement is believed to be one of the biggest challenges to the study and biomedical employment of glycoproteins [10], a multitude of alternative synthetic methods have been developed in recent years for the production of chemically glycosylated proteins $[11,12]$. 
However, most of the scientific insights concerning the effects of glycans on protein biophysics have been derived from the study of the genetic glycosylated proteins $[13,14]$.

Lipases are well known hydrolases capable of hydrolyzing the ester bonds of water-insoluble substrates at the interface between substrate and water, which show remarkable levels of activity and stability in non-aqueous environments, in contrast to many other enzymes [15]. Due to these unique properties, lipases are the most attractive enzymes for use in various industrial applications, such as in the food processing industry $[16,17]$ and in the energy industry for biodiesel production $[18,19]$. Protein engineering and optimization of lipase production systems make it possible to increase lipase productivity while decrease in product cost [20]. The production of active lipases has been performed in Escherichia coli [21], in Saccharomyces cerevisiae [22,23] and in P. pastoris [24-26]. Using E. coli as host encounter problems on lacking of post-transcriptional modification and formation of inclusion body and proteins expressed in $S$. cerevisiae are usually hyperglycosylated with high mannose glycans. P. pastoris expression system offers advantages of moderate glycosylation, tightly regulation, high level protein expression compared to E. coli and S. cerevisiae. Glycosylation of lipases expressed in yeast has multieffects on their expression and properties. N-glycosylation on the lipases from Rhizomucor miehei was important for the secretion of the enzyme [27]. N-glycosylation of lipases from $R$. miehei and $R$. oryzae had a negative effect on the lipase activities $[27,28]$. The N-glycosylated Thermomyces lanuginosus lipase exhibited better thermostability than their non-glycosylated variants [29].

In our previous studies, the lipase gene from Rhizopus chinensis (GenBank accession no. EF405962) was cloned and expressed in P. pastoris [30]. A chimeric lipase from $R$. oryzae replaced with the prosequence from $R$. chinensis lipase (RCL) successfully expressed in P. pastoris at highlevel, which was 11-fold higher than the wild type $R$. oryzae lipase (ROL) [31]. Three potential N-glycosylation sites are found in the propeptide of RCL, while ROL possesses only one potential $\mathrm{N}$-glycosylation site in its prosequence (Figure 1A). These findings inspired us to explore whether $\mathrm{N}$-glycosylation exists in the propeptide of RCL and how glycosylation affects the function of RCL. In this study, we generated a series of glycosylation mutants of RCL, by substituting the $\mathrm{N}$-linking site with $\mathrm{Q}$, and then we examined the expression levels of the $\mathrm{N}$-glycosylation mutants. The roles of $\mathrm{N}$-glycosylation on the protein expression, enzyme activity and thermostability of RCL were discussed.

\section{Results}

Sequence analysis of the gene encoding $R$. chinensis lipase The RCL sequence contains one complete open reading frame without introns, which encodes a 389 amino acid protein including a 26 amino acid signal sequence, 94 amino acid prosequence and 269 amino acid mature lipase sequence (Figure 1B). As shown in Figure 1B, RCL has four potential N-linked glycosylation sites, three of which lie in the prosequence $(\mathrm{N}-14, \mathrm{~N}-48, \mathrm{~N}-60)$ and the fourth $(\mathrm{N}-263)$ is in the mature region. Because a Kex2 cleavage site at $K^{66} R^{67}$ is present in the prosequence, the $R$. chinensis prolipase (proRCLC) expressed in P. pastoris was truncated by Kex 2 endoprotease. The resulting product was the mature lipase attached with 27 amino acids of the carboxy-terminal part of the prosequence, containing an his tag, named r27RCLC (Figure 1C), in which three potential $\mathrm{N}$-glycosylation sites in the propeptide were removed, retained only one potential glycosyaltion site $(\mathrm{N}-263)$ in the mature region. After $\mathrm{K}^{66} \mathrm{R}^{67}$ in the prosequence was mutated into $\mathrm{N}^{66} \mathrm{Q}^{67}, \mathrm{RCL}$ expressed in $P$. pastoris was no longer cleaved by Kex2, which contains an entire prosequence and mature sequence, named proRCLCNQ (Figure 1C).

\section{Treatment of proRCLCNQ and r27RCLC with glycosidase}

The molecular weight of purified r27RCLC and proRCLCNQ were evaluated by SDS-PAGE and western blotting. The mass of r27RCLC (Figure 2A: Lane 3) was $37 \mathrm{kDa}$, which was higher than the calculated molecular weight of $32.27 \mathrm{kDa}$, while the mass of proRCLCNQ smeared between $66.2 \mathrm{kDa}$ and $116 \mathrm{kDa}$ (Figure 2A: Lane 1), which was much higher than the calculated molecular weight of $40.5 \mathrm{kDa}$ [32]. After digestion with glycosidase PNGase F, SDS-PAGE analyses showed that the molecular mass of proRCLCNQ was reduced to approximately $45 \mathrm{kDa}$ (Figure 2A: Lane 2), and the band was no longer smeared. Western blotting analyses confirmed that the band of proRCLCNQ (Figure 2B: Lane 2) treated with PNGase F shifted down, indicating that proRCLCNQ is a glycoprotein. In contrast, the mass of r27RCLC (Figure 2A: Lane 4) did not change in the SDS-PAGE after treatment with PNGase F, compared with the band of r27RCLC without treatment with glycosidase (Figure 2A: Lane 3). Western blotting analyses verified that the band of r27RCLC was the same before (Figure 2B: Lane 3) and after treatment with PNGaseF (Figure 2B: Lane 4), suggesting that r27RCLC was not N-glycosylated, that is the only potential N-glycosylation site at N-263 in the mature region was not glycosylated.

\section{Identification of the $\mathrm{N}$-glycans in proRCLCNQ}

Each putative glycosylation site in the prosequence of proRCLCNQ was examined using site-directed mutagenesis from $\mathrm{N}$ (Asn) to $\mathrm{Q}$ (Gln). The $\mathrm{N}$-glycosylation mutants of proRCLCNQ at the sites N-14, N-48 and N60 were named proRCLCN14Q, proRCLCN48Q and proRCLCN60Q, respectively. Because protein proRCLCN $60 \mathrm{Q}$ was not detected in the culture medium, we did not 


\section{A Prosequence

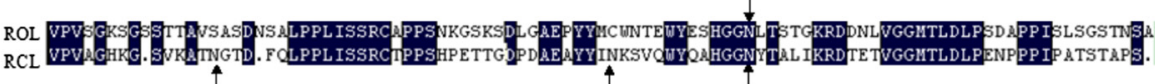 \\ B

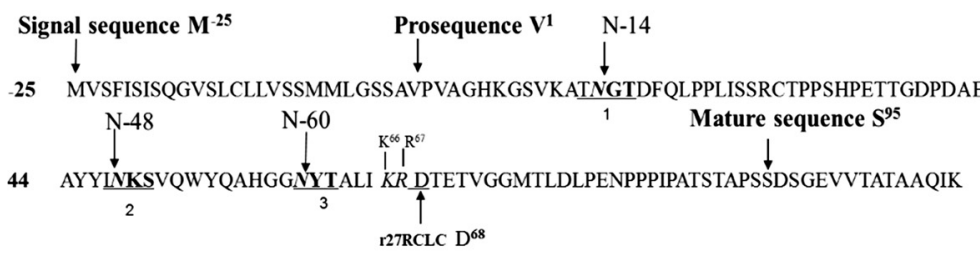

110 E LTNYAGVAATAYCRSVVPGTKWDCKQCLKYVPDGKLIKTFTSLLTDTNGFILRSDAQKTIYVTFRG

177 TNSFRSAITDMVFTFTDYSPVKGAKVHAGFLSSYNQVVKDYFPVVQDQLTAYPDYKVIVTGHSLGG

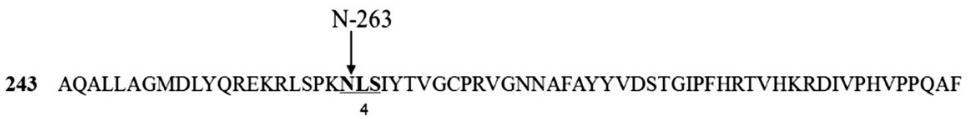

309 GYLHPGVESWIKEDPADVQICTSNIETKQCSNSIVPFTSIADHLTYF GINEGSCLHHHHHH

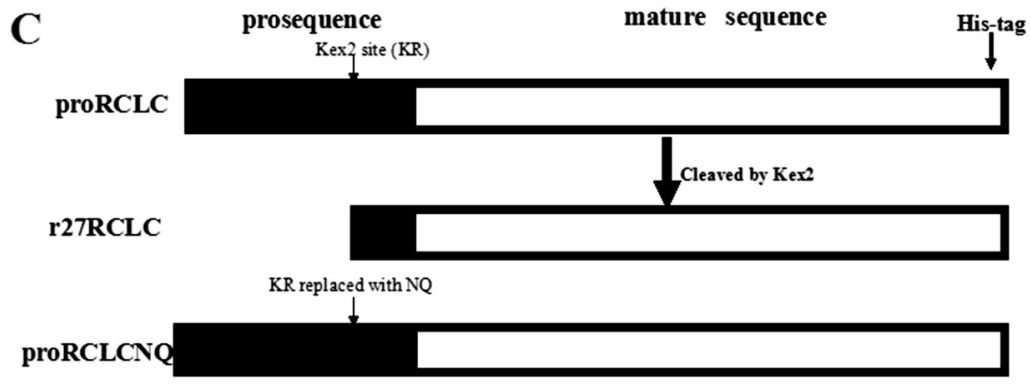

Figure 1 Sequence analysis of the gene encoding R. chinensis lipase. A. Alignment of the prosequence from $R$. oryzae lipase and $R$. chinensis lipase. Potential N-glycosylation sites were indicated by arrows; $\mathbf{B}$. Amino acid sequence of $R$. chinensis lipase. All potential N-glycosylation sites of RCLC predicted through glycomod (http://web.expasy.org/glycomod/) were highlighted in bold font (N-14, N-48, N-60, N-263), and the initial amino acid of the signal sequence, prosequence and mature sequence were marked. The cleavage site- $K^{66} R^{67}$ of Kex 2 is indicated in italic font; C. Schematic of lipases proRCLCNQ and r27RCLC.

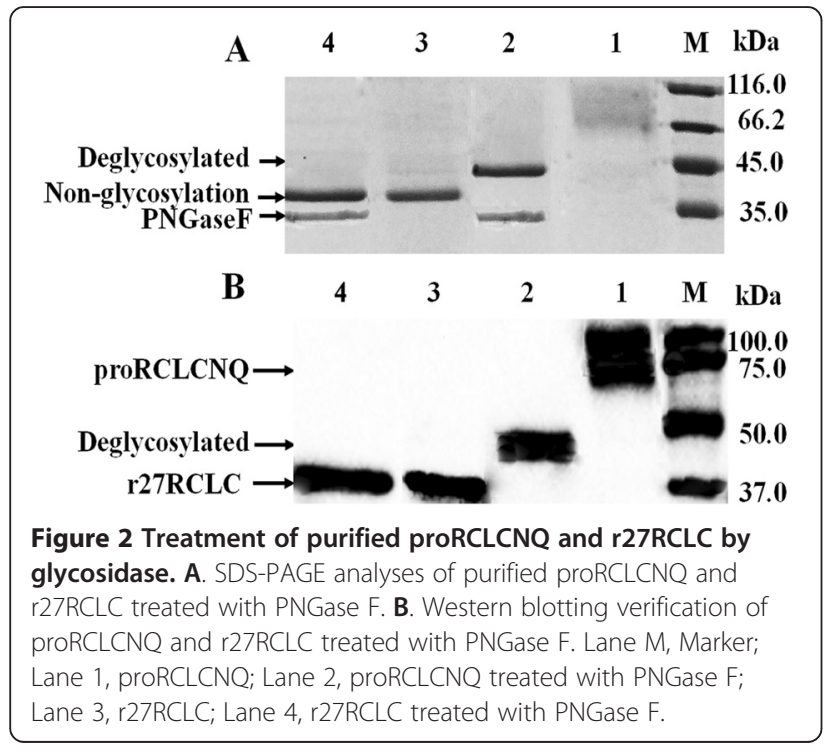

perform the treatment with glycosidase on it. SDS-PAGE was used to analyze the digestion of purified lipases with PNGase F (Figure 3). The mass of proRCLCN48Q did not change compared with proRCLCNQ, suggesting that the N-48 site was probably not glycosylated. The molecular mass of proRCLCN14Q, in which the glycosylation site at N-14 was deleted, showed a downward shift on SDS-PAGE compared with proRCLCNQ, indicating the

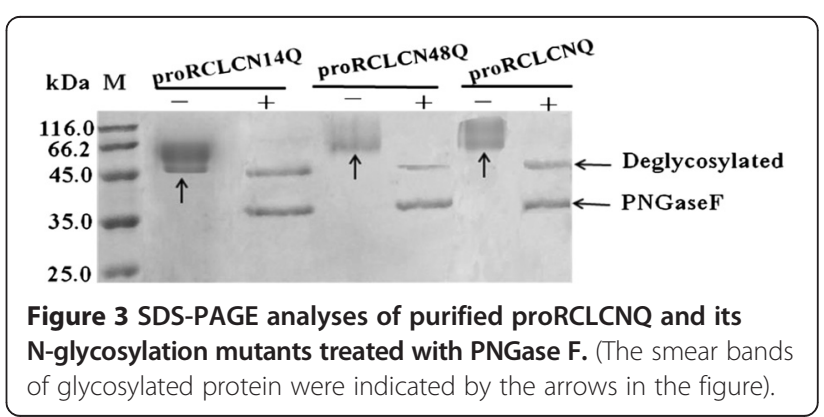


site N-14 was glycosylated. After treated with PNGase F, the mass of proRCLCN14Q demonstrated an additional reduction to approximately $45 \mathrm{kDa}$ and exhibited a single band (Figure 3), indicating that the site N-60 was glycosylated.

\section{Validation of the N-glycan in proRCLCNQ by LC-MS/MS analysis}

The extracted ion chromatography of the deamindated peptides ${ }^{12} \mathrm{~A}-\mathrm{R}^{27}$ in control or treatment with PNGase $\mathrm{F}$ were shown in Figure 4. The spectra of the deamindated peptides ${ }^{12} \mathrm{~A}-\mathrm{R}^{27}$ were significantly increased after treatment with PNGase F, indicating the significant amount of the sites N-14 in proRCLCNQ were N-glycosylated. In Figure 5, the extracted ion chromatography of the peptides ${ }^{39} \mathrm{D}-\mathrm{K}^{49}$ containing the site $\mathrm{N}-48$ showed that the deamindated peptide (the second row) was slightly increased after treatment with PNGase F (the fourth row) and the majority of peptide (the first row) had no change after treatment with PNGase F (the third row), indicating only a small portion of the sites $\mathrm{N}-48$ were glycosylated and the majority of the peptides were not modified. On the other hand, in Figure 6, the spectrum of deamindated peptide ${ }^{50} \mathrm{~S}-\mathrm{Q}^{67}$ (the second row) was significantly increased after treatment with PNGase F (the fourth row), suggesting that the significant amount of the sites N-60 in proRCLCNQ were N-glycosylated. The MS/MS spectra of the three peptides mentioned above were shown in Figure 7. For the site N-263, LCMSMS results certified that this site was not glycosylated (data not shown).

\section{Expression of $\mathrm{N}$-glycosylation mutants in $\mathrm{P}$. pastoris}

To investigate the role of the carbohydrate chain attached to proRCLCNQ, we compared the extracellular secretion level and enzymatic activity of proRCLCNQ with its $\mathrm{N}$-glycosylation mutants and the truncated r27RCLC in P. pastoris. All recombinant strains contained only one copy of the integrated lipase gene. The cell growth rates of all recombinant strains were comparable during the cultivation period (Figure 8A). As shown in Figure 8B, the enzyme activity of proRCLCN60Q was not detected, while those of proRCLCNQ, proRCLCN14Q and proRCLCN48Q were almost the same. However, compared with r27RCLC, the activities of proRCLCNQ and its mutants were much lower (Figure 8B). The kinetic assay (Table 1) also showed that the $k_{\text {cat }}$ and $k_{\text {cat }} / K_{\mathrm{m}}$ values for r27RCLC were the highest. On the other hand, the $k_{\text {cat }}$ and $k_{\text {cat }} / K_{\mathrm{m}}$ values for proRCLCNQ and proRCLCN48Q were very close, which were much higher

\section{${ }^{12}$ ATNGTDFQLPPLISSR ${ }^{27}$}

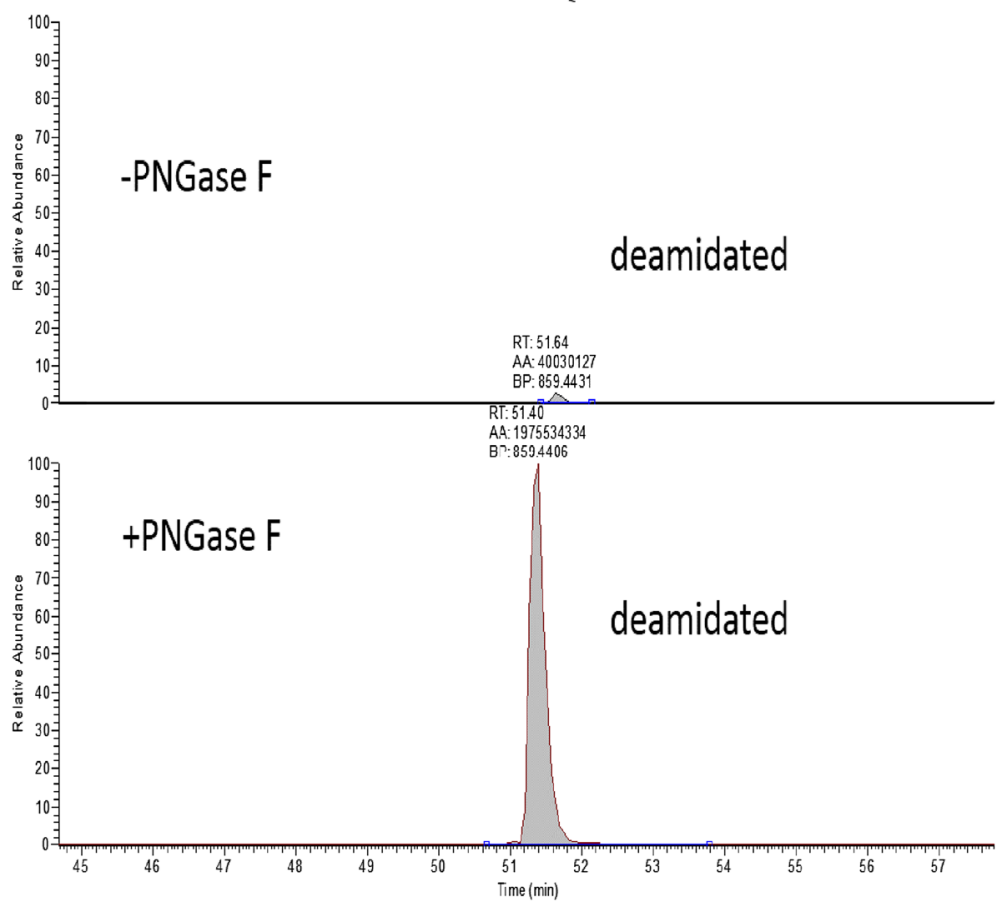

Figure 4 Extracted ion chromatography of deamindated peptide ${ }^{12} A-R^{27}$ from proRCLCNQ. The deamindated peptide ${ }^{12} A T N^{14} G T D F Q L P P L I S S R{ }^{27}$ was identified in tryptic digest before control (-PNGase F) or after treatment with PNGase F samples. The confirmed N-glycosylation site were marked in red. The automatic peak integration were indicated as AA. The peaks were scaled to 1.29 E8 as $100 \%$ for both panels. 


\section{${ }^{39}$ DPDAEAYYINK ${ }^{49}$}

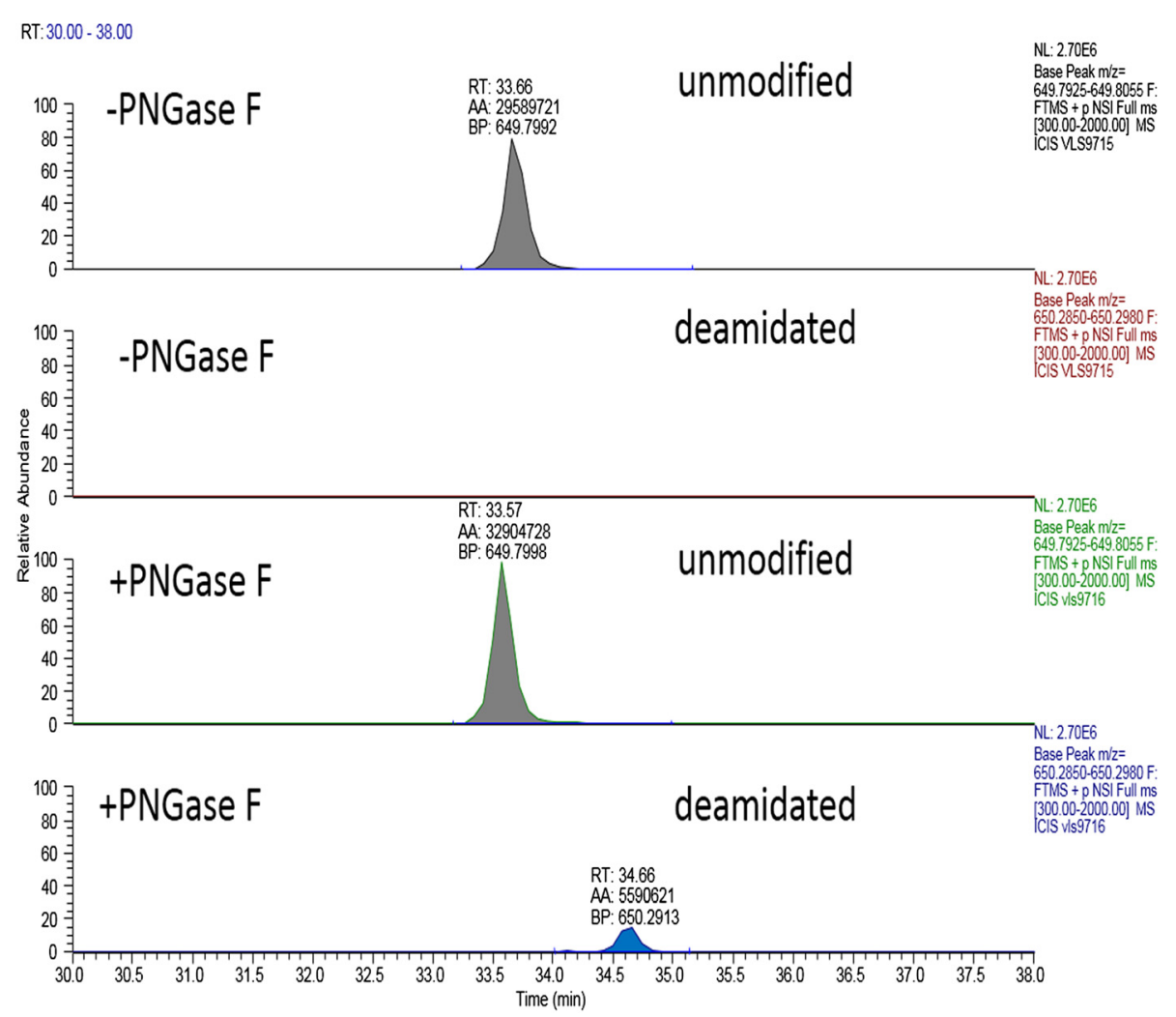

Figure 5 Extracted ion chromatography of peptide ${ }^{39} \mathrm{D}-\mathrm{K}^{49}$ from proRCLCNQ. The unmodified and deamindated peptides ${ }^{39} \mathrm{DPDAEAYYIN}{ }^{48} \mathrm{~K}^{49}$ in control (-PNGase F) or after treatment with PNGase F samples obtained by AspN and trypsin double digestion were indicated in the figure. The confirmed $\mathrm{N}$-glycosylation site were marked in red. The automatic peak integration of area under the curve were indicated as AA. The peaks were scaled to 2.7 E6 as $100 \%$ for all panels.

than that of proRCLCN14Q losing the N-14 glycan. In Figure 8C, the total protein concentration of proRCLCN60Q was the lowest compared with others. Western blotting analyses (Figure 9) confirmed the bands of extracellular proRCLCNQ, proRCLCN14Q and proRCLCN48Q. In agreement with no activity detected for proRCLCN60Q, no Western blotting band was observed for this mutant. We further analyzed the transcription levels of the r27RCLC, proRCLCNQ and proRCLCN60Q genes by RTPCR. Their transcription levels were almost the same at cultivation of $84 \mathrm{~h}$, suggesting that the $\mathrm{N}$-glycosylation mutation in the gene did not affect its transcription. We speculated that protein proRCLCN60Q was retained in yeast cells. Thus, the intracellular activity was measured and the intracellular lipase was analysis using Western blotting. Unfortunately, neither the intracellular $\mathrm{N}$-glycosylation mutants (proRCLCN14Q, proRCLCN48Q, proRCLCN60Q) nor the parent proRCLCNQ could be detected on Western blotting.
Effects of N-glycan chains on enzyme stability

To determine the effect of glycosylation on proRCLCNQ heat resistance, the thermostability of $\mathrm{N}$-glycosylation mutants at different temperatures $\left(25^{\circ} \mathrm{C}-55^{\circ} \mathrm{C}\right)$ retained $1 \mathrm{~h}$ was determined, and the results were illustrated in Figure 10. The lipases proRCLCNQ and proRCLCN48Q had about $70 \%$ residual activity after incubation for $1 \mathrm{~h}$ at $50^{\circ} \mathrm{C}$, while the residual activity of r27RCLC was only $40 \%$ at the same time. On the other hand, the residual activity of proRCLCN14Q losing one $\mathrm{N}$-glycan was lower than that of proRCLCNQ.

\section{Structural characteristics of secreted N-glycosylation mutants}

The structure of the secreted N-glycosylation mutants was characterized using $\mathrm{CD}$ spectra in the far-UV region (Figure 11). The $\mathrm{CD}$ spectrum of the glycoprotein proRCLCNQ showed a left-shift in wavelength range of 200-230 nm compared with r27RCLC. The spectrum of 


\section{${ }^{50 S V Q W Y Q A H G G N Y T A L I N Q 67}$}

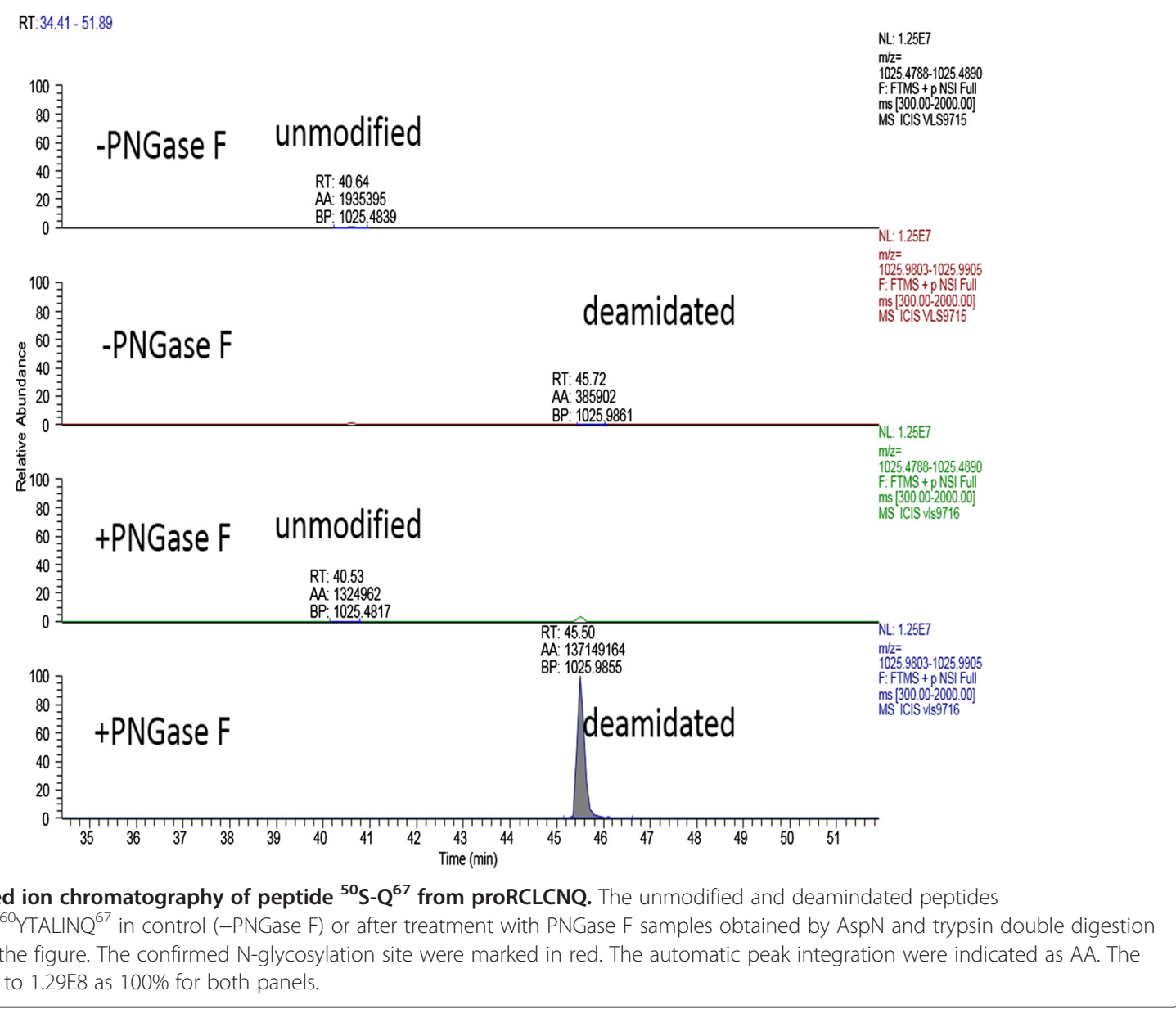

the mutant proRCLCN14Q mutant was similar to that of proRCLCNQ.

\section{Effects of organic solvents on lipase stability}

The retained activities of enzymes after exposure to various organic solvents $(90 \%(\mathrm{v} / \mathrm{v}))$ at $20^{\circ} \mathrm{C}$ for $24 \mathrm{~h}$ were shown in Table 2 . In the selected organic solvents, the relative activities of glycosylated proRCLCNQ and proRCLCN14Q were conspicuous higher than that of non-glycosylated r27RCLC. On the other hand, the residual activity of proRCLCN14Q losing one N-glycan was lower than that of proRCLCNQ. Furthermore, the relative activity of RCL in the presence of DMSO, N, Ndimethylformamide and dichloromethane was less than in the presence of hydrophobic solvents $\mathrm{N}$-hexane and Isooctane. RCL may be more stable in the hydrophobic solvents than the polar solvents. These results indicated that the $\mathrm{N}$-glycan may play a vital role for organic solvent-tolerance of RCL, especially solvents such as Nhexane and Isooctane.

\section{Discussion}

In this study, we examined the potential $\mathrm{N}$-glycosylation sites of RCL, and then discussed the functional significance of N-glycosylation on its secretion and enzymatic properties. RCL has four potential glycosylation sites in its gene sequence, three of which lie in the prosequence and the fourth of which is in the mature sequence (Figure 1B). Although the potential N-glycosylation sites of a protein can be predicted from the consensus sequence Asn-Xaa-Ser/Thr, not all such sites are fully occupied [33]. When RCL was expressed in P. pastoris, its $\mathrm{N}$-terminal was truncated by Kex2. Thus, the three potential glycosylation sites in its prosequence were removed and only one glycosylation site at N-263 was retained in the truncated lipase r27RCLC (Figure 1). Enzymatic deglycosylation, which removed both highmannose, hybrid-and complex-type N-linked glycans, was performed using glycosidases to investigate whether the potential glycosylation sites were glycosylated or not [3]. Endo $\mathrm{H}_{\mathrm{f}}$ cleaved within the chitobiose core of high 


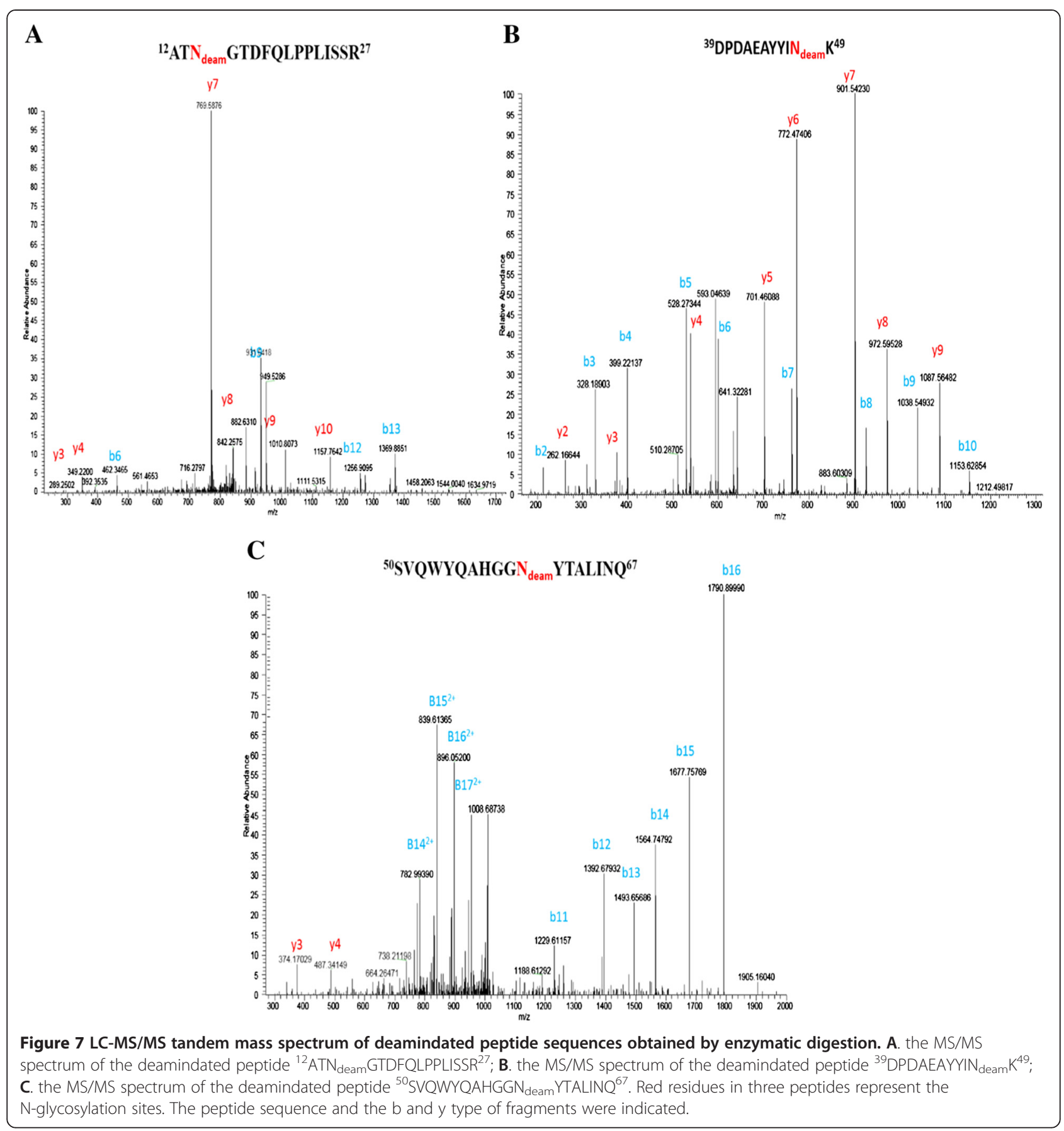

mannose and some hybrid oligosaccharides from $\mathrm{N}$ linked glycoproteins, leaving the innermost $\mathrm{N}$-acetylglucosamine intact [34]. Peptide-N-Glycosidase F (PNGase $\mathrm{F})$ is an amidase that cleaves between the innermost GlcNAc and asparagine residues of high mannose, hybrid, and complex oligosaccharides from N-linked glycoproteins [35]. On SDS-PAGE the band of r27RCLC digested with PNGase F were the same as the non-treated r27RCLC, indicating that the glycosylation site at N-263 was not glycosylated (Figure 2). Therefore, the site N-263 has no effect on the enzyme properties or the secretion of lipase. To investigate the effect of glycosylation in the prosequence of RCL, we constructed a mutant in which the Kex2 cleavage site- $\mathrm{K}^{66} \mathrm{R}^{67}$ of $\mathrm{RCL}$ was mutated into $\mathrm{N}^{66} \mathrm{Q}^{67}$ and subsequently expressed in P. pastoris GS115 to produce RCL containing its intact prosequence, named proRCLCNQ. To determine the contribution made to the molecular weight of recombinant proRCLCNQ by $\mathrm{N}$ linked glycans, enzymatic deglycosylation was therefore performed using glycosidases. A reduction in the molecular 

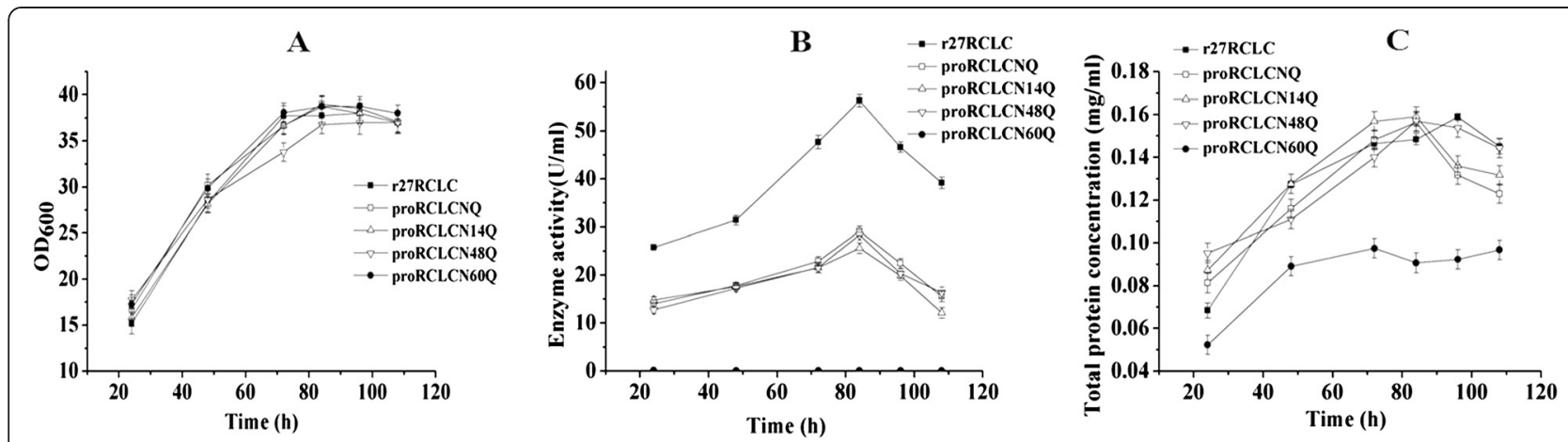

Figure 8 Growth, extracellular enzyme activity and total protein concentration profiles of lipases. A. Growth profiles of $r 27 R C L C$,

proRCLCNQ and the N-glycosylation mutants; $\mathbf{B}$. Extracellular enzyme activity of lipases. The curves were obtained from data of three independent experiments; $\mathbf{C}$. Total protein concentration of lipases from culture supernatants. The curves were obtained from data of three independent

experiments.

mass of proRCLCNQ after treatment with glycosidase (Figure 2) demonstrated that proRCLCNQ is a glycosylated protein. The band of non-treated proRCLCNQ smeared and was higher than its calculated molecular weight. This discrepancy can be explained by the fact that varying conformations of the sugar moieties can alter the interactions with the electrophoresis gel or extent of SDS binding which finally results in an electrophoretic behavior which does not reflect the correct size of the corresponding protein [36]. Further studies by glycosidase digestion and nano-LC-MS/MS analysis of proRCLCNQ demonstrated that the majority of the sites $\mathrm{N}-14$ and N60 were glycosylated, while the glycosylation degree of the site N-48 was only a small portion. The very little amount of glycan on N-48 had no effect on the secretion and enzyme activity of RCL. However, after deletion of the glycan on N-60, the mutant proRCLCN60Q failed to be secreted into the supernatant (Figure 9) and also could not be detected in the cell extract. The result of RT-PCR showed that the transcription level of proRCLCN60Q was almost the same as that of proRCLCNQ, which suggested that the dramatic difference in the secretion level between proRCLCNQ and proRCLCN60Q was not caused by transcription. Christian et al. [7] confirmed that the glycan structures of the dirigent protein AtDIR6 in P. pastoris are essential for solubility, structure and function of the protein because deglycosylation induced conformational

Table 1 Enzyme kinetic parameters of the purified r27RCLC, proRCLCNQ and its N-glycosylation mutants

\begin{tabular}{llll}
\hline Enzyme & $\boldsymbol{k}_{\text {cat }}\left(\mathbf{s}^{-\mathbf{1}}\right)$ & $\boldsymbol{K}_{\mathbf{m}}(\mathbf{m M})$ & $\boldsymbol{k}_{\text {cat }} / \boldsymbol{K}_{\mathbf{m}}\left(\mathbf{M}^{-1} \mathbf{s}^{-\mathbf{1}}\right)$ \\
\hline r27RCLC & $121.54 \pm 3.1$ & $0.34 \pm 0.10$ & $(3.56 \pm 0.81)^{*} 10^{5}$ \\
proRCLCNQ & $60.70 \pm 2.2$ & $0.20 \pm 0.04$ & $(2.92 \pm 0.55)^{*} 10^{5}$ \\
proRCLCN14Q & $24.82 \pm 2.4$ & $2.01 \pm 0.12$ & $(1.22 \pm 0.15)^{*} 10^{5}$ \\
proRCLCN48Q & $61.33 \pm 2.5$ & $0.19 \pm 0.02$ & $(3.11 \pm 0.61)^{*} 10^{5}$ \\
\hline
\end{tabular}

changes leading to the complete loss in dirigent activity and subsequent protein aggregation. In our experiment the N-60 glycan on proRCLCNQ may influence the proper translation or the correct folding of the enzyme, resulting proRCLCN60Q was not produced or the misfolded protein may be rapidly degraded, which could not be detected by Western blotting. Some scholars reported that glycans can play key roles in protein secretion or positioning. The glycosylation site in the peptide sequence of lysosomal renin represented the targeting signal that may as well serve for prorenin uptake via the mannose-6phosphate receptor [37]. The N-glycosylation sites of the recombinant elastase were necessary for its high-level expression in P. pastoris [38]. Gwen et al. [39] demonstrated that human endothelial lipase was a glycosylated protein and that the efficient secretion of the enzyme was dependent on the presence of the N-linked carbohydrate. In our study, the glycan on N-60 may play a key role in positioning the protein to endoplasmic reticulum or transporting the protein from endoplasmic reticulum to Golgi apparatus. In future study, we plan to use fusion expression with GFP to observe the intracellular positioning of proRCLCN60Q for elucidation of its mechanism.

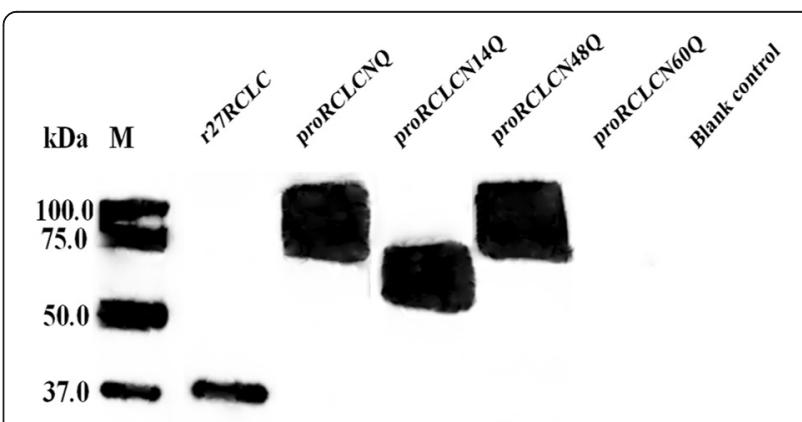

Figure 9 Western blotting analyses of r27RCLC, proRCLCNQ and the $\mathrm{N}$-glycosylation mutants from culture supernatant. 


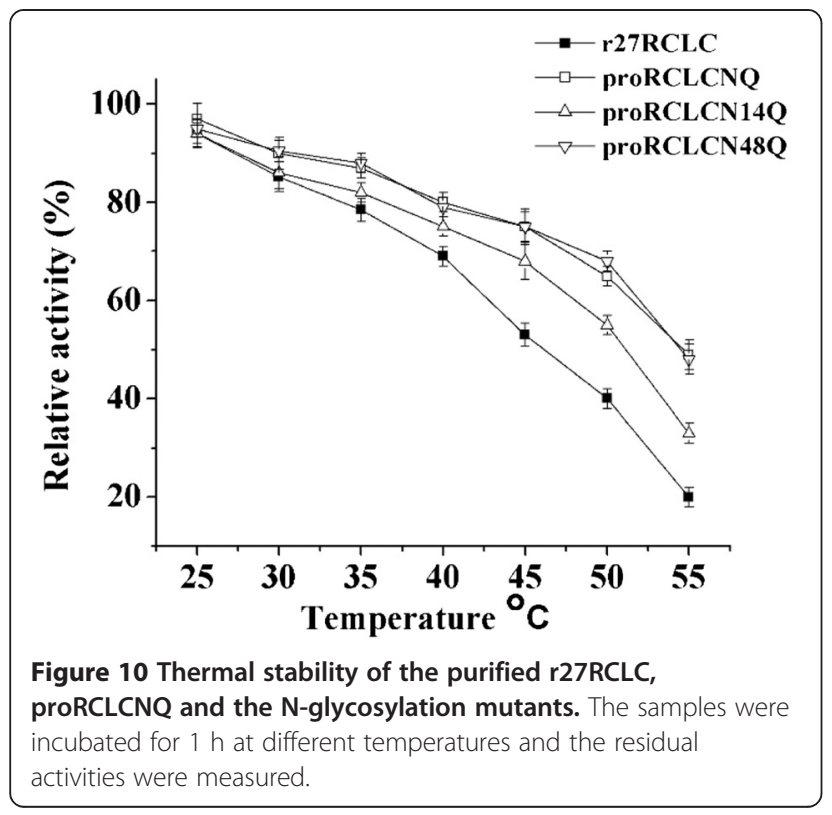

The secretion level of proRCLCN14Q was almost the same as proRCLCNQ (Figure 8C), which suggested that the glycan on N-14 had no effect on the secretion of this lipase. The $k_{\text {cat }}$ value of proRCLCN14Q losing N-14 glycan apparently decreased (Table 1), which indicated that the glycan on $\mathrm{N}-14$ probably assist in the protein folding, favoring a more beneficial conformation for higher activity. The important roles of $\mathrm{N}$-glycan in enzyme activity have been reported. Wei et al. [8] demonstrated that the N-glycan on $\mathrm{N}-224$ of $\beta$-Glucosidase in P. pastoris played a key role in protein native folding and catalytic activity. Kohler et al. [40] confirmed that the N-428 glycan of N-Acetylglucosamine-6-sulfotransferase-1 was critical for its enzyme activity.

The biomass and the extracellular total protein concentration of proRCLCNQ and proRCLCN14Q were very

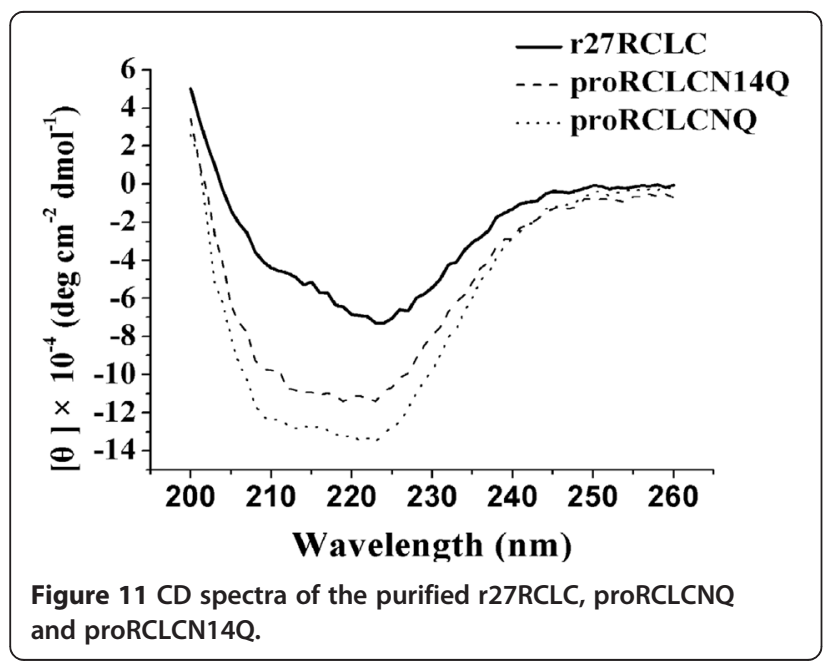

close to those of r27RCLC. However, r27RCLC showed the highest enzyme activity during cultivation (Figure $8 \mathrm{~B}$ ), which was in agreement with its highest $k_{\text {cat }}$ and $k_{\text {cat }} / K_{\mathrm{m}}$ values (Table 1). The existence of Kex2 cleavage site in the wild-type RCL resulted in the partially truncation of the prosequence in Golgi apparatus, forming r27RCLC. The higher enzyme activity of the truncated r27RCLC indicated that the intact prosequence negatively affects the activity of RCL. The CD spectrum of glycoprotein proRCLCNQ showed a more classical $\alpha$-helix structure in the wavelength range of 200-230 nm [6] compared with r27RCLC (Figure 11), which suggested that the intact prosequence altered the secondary structure of the lipase. Many proteins were synthesized in the form of precursor. After protein was folded into the mature form, its propeptide, an $\mathrm{N}$-terminal peptide chain, were then identified and excised by the corresponding protease [41]. The function of propeptide is mainly divided into two categories. Type I is mainly responsible for the correct folding of the protein. These kinds of enzymes could only be activated after excision of their propeptides, for example, subtilisin [42] and lytic protease [43]. Type II is involved in intracellular protein transportation and positioning, not directly involved in protein folding, for example, somatostatin II [44] and myeloperoxidase [45]. Our results revealed that the propeptide in RCL probably acts not only as the type I but also as the type II propeptide and the $\mathrm{N}$-glycan in the propeptide plays a key role.

In general, glycoproteins are more stable than their corresponding non-glycosylated counterparts, despite the lack of major structural changes associated with glycosylation [46]. Steric interactions between the sugar residues and protein structure have been reported to be involved in stabilizing the effects in many glycosylated proteins [47]. However, the sugar chains bound to $R$. niveus lipase [48] and $R$. oryzae lipase [28] had no effect on thermal stability, which demonstrated the different roles of sugar chains in the enzyme properties. Functionally active $\mathrm{N}$-glycosylation mutants of proRCLCNQ enabled the study of the effect of glycosylation on protein stability. The results demonstrated that glycoprotein proRCLCNQ, proRCLCN48Q and proRCLCN14Q were more thermostable than r27RCLC (Figure 10). The covalent addition of the glycans to the surface of proRCLCNQ may modulate its kinetic parameters and thermal stability due to the interactions between the protein and the attached glycans, demonstrating that glycosylation affects the protein energy landscape [49]. After the deletion of the glycan on N-14, compared with proRCLCNQ, the thermal stability of proRCLCN14Q decreased. The glycan on $\mathrm{N}-14$ of proRCLCNQ may improve the stability of the enzyme conformation by decreasing flexibility or adding rigidity to the enzyme structure [50,51]. On the other hand, the stability measurement of RCL in aqueous- 
Table 2 The relative activities of r27RCLC, proRCLCNQ and proRCLCN14Q that treated by $90 \%$ (v/v) organic solvents with different $\log P$ values

\begin{tabular}{|c|c|c|c|c|}
\hline \multirow[t]{2}{*}{ Organic solvent $(90 \% \mathrm{v} / \mathrm{v})$} & \multirow[t]{2}{*}{$\log P$} & \multicolumn{3}{|c|}{ Relative activities of lipases (\%) } \\
\hline & & r27RCLC & proRCLCNQ & proRCLCN14Q \\
\hline None & - & 100 & 100 & 100 \\
\hline DMSO & -1.49 & $29 \pm 3.5$ & $58 \pm 4.0$ & $51 \pm 4.2$ \\
\hline $\mathrm{N}, \mathrm{N}$-dimethylformamide & 0.07 & $18 \pm 4.3$ & $43 \pm 3.5$ & $35 \pm 3.1$ \\
\hline Dichloromethane & 1.01 & $8 \pm 1.5$ & $21 \pm 2.1$ & $16 \pm 1.1$ \\
\hline Toluene & 2.50 & $22 \pm 2.1$ & $39 \pm 2.5$ & $31 \pm 2.4$ \\
\hline N-hexane & 3.50 & $35 \pm 3.5$ & $66 \pm 3.1$ & $58 \pm 3.2$ \\
\hline Isooctane & 4.50 & $43 \pm 4.1$ & $78 \pm 3.5$ & $70 \pm 3.0$ \\
\hline
\end{tabular}

organic mixtures suggested that the N-glycans on RCL improved the enzyme stability in organic solvents. The effect of glycosylation on enzyme stability in organic solvents has rarely been investigated. Enzyme tolerance to organic solvents differed from lipase to lipase [52]. Zou et al. demonstrated the $\mathrm{N}$-glycans of $\beta$-glucuronidase increased its stability in DMSO and acetone [53]. The stability of the glycosylated lipase proRCLCNQ from $P$. pastoris in organic solvents made it hold the potential for its use in organic synthesis and related applications. And we also measured the substrate specificity of r27RCLC, proRCLCNQ and proRCLCN14Q towards $p$-Nitrophenyl monoesters $(C 2 \sim C 16)$. The results showed that the glycans on protein proRCLCNQ have no effect on the lipase substrate specificity (Data not shown).

\section{Conclusions}

In summary, this study demonstrated that RCL is $\mathrm{N}$ glycosylated when expressed in P. pastoris and confirmed the key role of the $\mathrm{N}$-glycosylation in the secretion, enzyme activity and stability of RCL. This report may also provide theoretical support for the improvement of enzyme expression and stability based on the N-linked glycosylated modification to meet the future needs of the biotechnological industry and provide excellent biological catalyst for the oil processing industry and other biotechnological industries.

\section{Material and methods}

\section{Enzymes and reagents}

Endo $\mathrm{H}_{\mathrm{f}}$ and PNGase $\mathrm{F}$ were purchased from New England BioLabs. $p$-nitrophenyl palmitate ( $p \mathrm{NPP})$, endoproteinase Asp-N and trypsion were obtained from Sigma (USA). Horseradish peroxidase-conjugated goat anti-mouse IgG, Anti-His antibody and Pro-LightHRP chemical reflective detection reagents was purchased from TianGen Biotech (Beijing, China). Western blotting Marker and nitrocellulose membrane (PVDF) were obtained from BIO-RAD. Dpn I, PrimeSTAR polymerase, PCR reagents were obtained from Takara Biotechnology (Dalian, China). SDS-
PAGE Protein Marker was provided by Beyotime Institute Biotechnology. Primers were synthesized at Sangon Bitech (Shanghai, China). Gel extraction and PCR purification kits were purchased from Bioflux (Hangzhou, China). A Plasmid Mini Kit I was obtained from OMEGA Bio-Tek. A One Step Yeast Active Protein Extraction Kit was purchased from Sangon Bitech. All other chemicals used were of the highest quality that is commercially available.

\section{Strains and plasmids}

P. pastoris GS115 and Plasmid pPIC9K were used as gene expression vector and purchased from Invitrogen. The constitutive recombinant plasmid pGAPK-proRCLC and the strain GS115/pGAPK-proRCLC expressing $R$. chinensis lipase were previously constructed in our lab [54]. Yeast nutrient medium MD-G418 and YPD-G418 were prepared using ' $P$. pastoris expression Kit' (Pichia Multi-Copy Expression Kit, version A, Invitrogen BV, The Netherlands).

\section{Construction of the recombinant $R$. chinensis lipase}

The mutation of the Kex2 cleavage site in RCL from $\mathrm{K}^{66} \mathrm{R}^{67}$ to $\mathrm{N}^{66} \mathrm{Q}^{67}$ was generated by point mutation using synthetic oligonucleotide primers (5' -CTACACTGCTC TTATCAACCAGGATACTGAAACCGTCG-3' and 5' CGACGGTTTCAGTATCCTGGTTGATAAGAGCAGT GTAG-3') with the plasmid pGAPK-proRCLC as the template. After the template was digested with $D p n$ I, the plasmid, named pGAPK-proRCLCNQ was transformed into $E$. coli JM109 competent cells as described by Hanahan [55]. Subsequently, the transformants were selected on an LB agar plate with ampicillin. After the mutation was verified using DNA sequencing, the recombinant plasmid pGAPK-proRCLCNQ was linearized with $B g l$ II and then transformed into P. pastoris GS115 competent cells by electroporation. The transformed cells were grown on an MD plate with G418 and cultured for the production of recombinant lipase named proRCLCNQ. 


\section{Construction of $\mathrm{N}$-glycosylation mutants}

Mutations in each of the glycosylation sites were generated by a point mutation as previously described, using the plasmid pGAPK-proRCLCNQ as the template. For each glycosylation site, the codon for $\mathrm{N}$ (Asn) was replaced by Q (Gln) at position 14, 48 and 60, respectively. The following sense oligonucleotides were used to generate the mutant of proRCLCN14Q, proRCLCN48Q and proRCLCN60Q, individually:

\section{5'-GTTCAGTCAAGGCAACTCAGGGCACCTTTGAC- AACTC-3'; \\ 5'-AGCTTACTATATTCAGAAGAGCGTTCAATGTAC CAAG-3'; \\ 5'-CAATGGTACCAAGCTCACGGTGGCCAGTACAC TTCTTATCAACC-3'.}

The methods for transformation and expression were the same as the procedure described above. All lipases in this study were constructed with a six-histidine tag at the $\mathrm{C}$-terminus.

\section{Expression in $P$. pastoris in shaking flasks}

The $P$. pastoris transformants were cultured in $100 \mathrm{ml}$ of YPD medium shaken at $30^{\circ} \mathrm{C}$ and $200 \mathrm{rpm}$ in $500 \mathrm{ml}$ glass flasks. The culture supernatant was collected every $12 \mathrm{~h}$ or $24 \mathrm{~h}$ to assay the cell density, protein concentration and lipase activity during culture.

\section{Determination of the extracellular secretion level and lipase activity}

Lipase activity was measured on emulsified $p$ NPP according to Kordel et al. [56].

One volume of a $1.08 \mathrm{mM}$ solution of $p \mathrm{NPP}$ in 2propanol was mixed just prior to use with nine volumes of $50 \mathrm{mM}$ PBS buffer $\mathrm{pH}$ 8.0, containing $4 \mathrm{~g} / \mathrm{L}$ Triton $\mathrm{X}-100$ and $1 \mathrm{~g} / \mathrm{L}$ arabic gum. The standard reaction was $2.4 \mathrm{~mL}$ of the above substrate mixture and $0.1 \mathrm{~mL}$ of enzyme solution at an appropriate dilution in $50 \mathrm{mM} \mathrm{pH} 8.0$ PBS buffer at $40^{\circ} \mathrm{C}$ for $2 \mathrm{~min}$. The absorbance at $410 \mathrm{~nm}$ of the reactant against a blank without enzyme was monitored using a UV-vis spectrophotometer (UNICO UV3102 PC, China). One enzyme unit was defined as the amount of enzyme releasing $1 \mu \mathrm{mol}$ of $p$-nitrophenol per minute under the assay conditions $\left(\mathrm{pH} 8.0,40^{\circ} \mathrm{C}\right)$. SDSPAGE and Western blotting analyses were used to analyze the secretion level of the mutants. The protein concentration was determined using a Bradford assay. Bovine serum albumin (BSA) was used as a standard.

\section{Analyses of the intracellular expression level of $\mathrm{N}$-glycosylation mutants}

For the assays of intracellular protein and activity, cells expressing each of the $\mathrm{N}$-glycosylation mutants were harvested every $12 \mathrm{~h}$ from $24 \mathrm{~h}$ until $96 \mathrm{~h}$ during culture and were separated by centrifugation $(7000 \times \mathrm{g}$ for $10 \mathrm{~min}$ ). Next, the cells were lysed using a One Step Yeast Active Protein Extraction Kit, which consisted an extraction reagent, a protease inhibitor, DTT and PMSF solution. The lysates were used to analyze the lipase activity and were subjected to Western blotting analyses to monitor intracellular proteins.

\section{Transcription level of the lipase gene}

The transcription levels of the lipase genes in the constructed recombinant strains after cultivation of $84 \mathrm{~h}$ were analyzed using reverse transcription-polymerase chain reaction (RT-PCR) normalized with Actin gene as the housekeeping gene. RNA was isolated using Yeast RNAiso Kit (TaKaRa Bio Co., Ltd). RNA integrity was tested in $1.2 \%$ agarose gels and its concentration was measured by densitometry and by $260 / 280 \mathrm{~nm}$ absorbance ratio. Five hundred nanograms of total RNA were subjected to reverse transcription using AMV First Strand cDNA Synthesis Kit (Sangon Bio Co., Ltd). The reaction was terminated by heating at $70^{\circ} \mathrm{C}$ for $10 \mathrm{~min}$. Synthetic primers used in RT-PCRs are as follows. ActinF: 5'-TGGTAACGAAAGATTCAGAGCC -3', Actin-R: 5'-TGATGGAGTTGTAAGTAGTTTGGTC-3'; Target-F:

\section{5'-GGTTGTCCTCGTGTCGGTAA-3', Target-R: 5' -GATTTGAACATCAGCAGGGTCT-3'}

Samples were run in triplicate in optical 96-well PCR plates with values falling within $\pm 1 \%$. Running conditions included $25 \mu \mathrm{l}$ final volume, $25 \mu \mathrm{l} 2 \times$ SYBR mix, 1-100 ng DNA, and $10 \mu \mathrm{M}$ reverse and forward primers. Control samples included a minus RT sample to ensure that there was no DNA contamination. Analysis was performed using a comparative $\left(\Delta \mathrm{C}_{\mathrm{t}}\right)$ approach. Additionally, a standard curve using dilutions of the sample was created.

\section{Purification of lipases}

The selected yeast strain was grown in $100 \mathrm{ml}$ YPD medium for $72 \mathrm{~h}$, and then the culture medium was centrifuged $(7000 \times \mathrm{g}, 30 \mathrm{~min})$ to remove cells. The histidinetagged lipases from the culture supernatant were purified using Ni-NTA chromatography by ÄKTA purifier (GE Co.). Lipases were then concentrated by ultrafiltration through a $10-\mathrm{kDa}$ membrane (Millipore, USA). The purity of the proteins was monitored using SDS-PAGE. The purification methods of all lipases mentioned in the paper were the same as above.

\section{SDS-PAGE and Western blotting analyses}

Denaturing SDS-PAGE was performed as previously described by Laemmli [57]. Protein samples were subjected 
to $12 \%$ SDS-PAGE using a Mini-Protein II Cell (Bio-Rad). Proteins were stained with Coomassie bright blue and quantified using a Molecular Imaging System, with the low protein ladder (Takara, china) as a standard. For Western blotting analysis, the proteins were separated using electrophoresis and then transferred onto a Protran nitrocellulose membrane using a Mini Trans-Blot Cell (Bio-Rad). A purified Anti-His Antibody raised against the purified RCL was used as the primary antibody and was diluted 1:1,000 prior to application. Horseradish peroxidaseconjugated goat anti-mouse IgG was diluted 1:500 as the secondary antibody. An immunoblot assay system (BioRad Laboratories) was used to quantify the relative amount of protein.

\section{Glycosidase digestions}

Protein samples $(0.025 \mathrm{mg} / \mathrm{ml})$ were boiled for $10 \mathrm{~min}$ in denaturing buffer containing 0.4 M DTT and 0.5\% SDS to fully expose all of the glycosylation sites, and deglycosylation was then performed by treatment with Endo $\mathrm{H}_{\mathrm{f}}$ or PNGase $\mathrm{F}$ at $37^{\circ} \mathrm{C}$ for overnight according to the instructions of the manufactures. The buffers used in these enzyme reactions were $50 \mathrm{mM}$ sodium citrate $(\mathrm{pH} 5.5)$ for $\mathrm{EndoH}_{\mathrm{f}}$ and $50 \mathrm{mM}$ sodium phosphate (pH 7.5) containing 1\% Nonidet P-40 for PNGase F. The supernatant $(20 \mu \mathrm{l})$ of each culture medium was subjected to SDSPAGE and Western blotting analyses.

\section{In-gel digestion}

$5 \mu \mathrm{g}$ of protein were separated on SDS-PAGE and the visible bands were excised and combined for in-gel tryptic digestion. Standard protocol was used for reduction, acylation and in-gel tryptic digestion and peptide extraction. For PNGase F treatment, in-gel digested peptides were divided to 2 equal aliquots and solubilized in $50 \mathrm{mM} \mathrm{NH} \mathrm{NH}_{4} \mathrm{HCO}_{3}$. One aliquot was digested with PNGase $\mathrm{F}$ at $37^{\circ} \mathrm{C}$ for 2 hours (+PNGase $\mathrm{F}$ ) and the other aliquot was incubated alongside without PNGase F as control (-PNGase F). The reaction was stopped by addition of 10\% TFA to adjust $\mathrm{pH}$ to 3 before LC-MS/MS.

\section{LC-MS/MS and data analysis}

LC-MS/MS was done using nano-LC-MS/MS using a Dionex RSLC system (ThermoFisher, San Jose, CA) interfaced with a LTQ Orbitrap Velos (ThermoFisher, San Jose, CA). Samples were loaded onto a self-packed $100 \mu \mathrm{m} \times 2 \mathrm{~cm}$ trap packed with Magic C18AQ, $5 \mu \mathrm{m}$ 200 A (Michrom Bioresources Inc, Aubum, CA) and washed with Buffer $\mathrm{A}$ ( $0.2 \%$ formic acid) for 5 min with flow rate of $10 \mu \mathrm{l} / \mathrm{min}$. The trap was brought in-line with the homemade analytical column (Magic C18AQ, $3 \mu \mathrm{m}$ $200 \mathrm{~A}, 75 \mu \mathrm{m} \times 50 \mathrm{~cm}$ ) and peptides fractionated at $300 \mathrm{nl} / \mathrm{min}$ with a multi-stepped gradient (4 to $15 \%$ Buffer B (0.16\% formic acid $80 \%$ acetonitrile) in $10 \mathrm{~min}$ and
$15-50 \%$ B in 40). Mass spectrometry data was acquired using a data-dependent acquisition procedure with a cyclic series of a full scan acquired in Orbitrap with resolution of 60,000 followed by MS/MS scans (CID $35 \%$ of collision energy) of 20 most intense ions with a repeat count of two and the dynamic exclusion duration of $60 \mathrm{sec}$. The LC-MS/MS data was searched against a custom fasta database including target protein sequences using X!tandem (SLEDGEHAMMER (2013.09.01), thegpm. org) with carbamidomethylation on cysteine as fixed modification and oxidation of methionine and deamidation on Asparagine as variable modifications using a $10 \mathrm{ppm}$ precursor ion tolerance and a $0.4 \mathrm{Da}$ fragment ion tolerance. Relevant peptides were manually inspected. Glycopeptides were interpreted by manual inspection of the LC-MSMS raw data.

\section{Kinetic parameters}

The kinetic parameters of purified enzymes were determined under the react condition of $\mathrm{pH} 8.0$ and $40^{\circ} \mathrm{C}$ using various concentrations of $p \mathrm{NPP}$ as substrate according to the method described by Burdette et al. [58].

\section{Thermostability analysis}

The purified lipases were incubated for $1 \mathrm{~h}$ at different temperatures and then the residual enzyme activities of lipases were measured at $40^{\circ} \mathrm{C}$ using $p \mathrm{NPP}$ as substrate by the standard enzyme activity detection method as previously described [56].

\section{Lipase treated with organic solvents}

The organic solvents were selected and classified according to their $\log P$ values [59]. Lipase was incubated in $90 \%(\mathrm{v} / \mathrm{v})$ of DMSO, $\mathrm{N}, \mathrm{N}$-dimethylformamide, dichloromethane, toluene, $n$-hexane and isooctane at $20^{\circ} \mathrm{C}$ and $200 \mathrm{rpm}$ for $24 \mathrm{~h}$. Stability of lipases in these organic solvents was probed by measuring the residual activity of the mixture, using $p$ NPP as substrate as previously described. The mixtures of lipases and PBS buffer $(50 \mathrm{mM}$, $\mathrm{pH}$ 8.0) were taken as control. The activity of the control was taken as $100 \%$.

\section{Circular Dichroism (CD) spectra}

CD spectra were taken on a MOS-450/AF-CD (Jasco), which was continuously purged with nitrogen. Measurement was performed at $25^{\circ} \mathrm{C}$ for a final concentration of $0.2 \mathrm{mg} / \mathrm{ml}$ in $10 \mathrm{mM}$ potassium phosphate buffer (pH 8.0) using the cell with $1.0 \mathrm{~mm}$ pathlength for farultraviolet CD spectra (200-260 nm). An average of three consecutive scans was taken for each sample. Each spectrum was represented as the mean residue ellipticity (degree $\mathrm{cm}^{-2} \mathrm{dmol}^{-1}$ ). 


\section{Abbreviations}

RCL: Rhizopus chinensis lipase; ROL: Rhizopus oryzae lipase; r27RCLC: Rhizopus chinensis mature lipase attached with 27 amino acids of the carboxy-terminal part of the prosequence; proRCL: Rhizopus chinensis lipase with intact prosequence; proRCLCNQ: Rhizopus chinensis lipase with intact prosequence with $\mathrm{K}^{66} \mathrm{R}^{67}$ mutated into $\mathrm{N}^{66} \mathrm{Q}^{67}$; proRCLCN14Q: The N-glycosylation mutant of proRCLCNQ at the site $\mathrm{N}-14$; proRCLCN48Q: The N-glycosylation mutant of proRCLCNQ at the site N-48; proRCLCN60Q: The N-glycosylation mutant of proRCLCNQ at the site N-60; YPD: Yeast extract peptone dextrose medium; GFP: Green fluorescent protein; Endo $H_{f}$ : Endoglycosidase $H_{f i}$ PNGase F: Peptide: N-glycanase F; pNPP: p-nitrophenyl palmitate.

\section{Competing interests}

The authors declare that they have no competing interests.

\section{Authors' contributions}

MY carried out the study, analyzed data and results, participated in the design and drafted the manuscript. X-WY participated in the design of the study, supervised the study and revised the manuscript. H-YZ, C-FZ, M-QQ carried out LC-MS/MS experiment and results analysis. All other authors have read and approved the final manuscript.

\section{Acknowledgments}

Financial support from the National High Technology Research and Development Program of China (863 Program) (No. 2012AA022207), the National Key Basic Research and Development Program of China (973 Program) (No. 2011CB710800), the High-end Foreign Experts Recruitment Program (GDW20123200113) and the 111 Project (111-2-06) are greatly appreciated. We also thank Professor Rong Xiao (Rutgers University) for kindly revising our manuscript. Financial support from NSFC (20802027).

\section{Author details}

${ }^{1}$ The Key Laboratory of Industrial Biotechnology, Ministry of Education, School of Biotechnology, Jiangnan University, 1800 Lihu Avenue, Wuxi 214122, Jiangsu, China. ${ }^{2}$ State Key Laboratory of Food Science and Technology, Jiangnan University, 1800 Lihu Avenue, Wuxi 214122, Jiangsu, China. ${ }^{3}$ Biological Mass Spectrometry Facility at Robert wood Johnson medical school and Rutgers, the state university of new jersey, Piscataway NJ 08854, USA.

\section{Received: 18 November 2014 Accepted: 11 March 2015}

Published online: 21 March 2015

\section{References}

1. Daly R, Hearn MT. Expression of heterologous proteins in Pichia pastoris: a useful experimental tool in protein engineering and production. J Mol Rec 2005;18:119-38.

2. Sørensen HP. Towards universal systems for recombinant gene expression. Microb Cell Fact. 2010;9:27.

3. Pratap J, Rajamohan G, Dikshit K. Characteristics of glycosylated streptokinase secreted from Pichia pastoris: enhanced resistance of SK to proteolysis by glycosylation. Appl Microbiol Biotechnol. 2000;53:469-75.

4. Parodi AJ. Reglucosylation of glycoproteins and quality control of glycoprotein folding in the endoplasmic reticulum of yeast cells. Biochem Biophy Acta. 1999;1426:287-95.

5. Helenius A, Aebi M. Intracellular functions of N-linked glycans. Science. 2001:291:2364-9.

6. Ito K, Seri A, Kimura F, Matsudomi N. Site-specific glycosylation at Asn-292 in ovalbumin is essential to efficient secretion in yeast. J Biochem. 2007;141:193-9.

7. Kazenwadel C, Klebensberger J, Richter S, Pfannstiel J, Gerken U, Pickel B, et al. Optimized expression of the dirigent protein AtDIR6 in Pichia pastoris and impact of glycosylation on protein structure and function. Appl Microbiol Biotechnol. 2013;97:7215-27.

8. Wei W, Chen L, Zou G, Wang Q, Yan X, Zhang J, et al. N-glycosylation affects the proper folding, enzymatic characteristics and production of a fungal $\beta$-glucosidase. Biochem Bioeng. 2013;110:3075-84.

9. Winiarska B, Dwornik A, Dębski J, Grzelak K, Bystranowska D, Zalewska M et al. N-linked glycosylation of $\mathrm{G}$ mellonella juvenile hormone binding protein-comparison of recombinant mutants expressed in $\mathrm{P}$ pastoris cells with native protein. Biochim Biophys Acta. 2011;1814:610-21.
10. Borman S. Glycosylation engineering. Chem Eng News. 2006;84:13-22.

11. Solá RJ, Griebenow K. Chemical glycosylation: new insights on the interrelation between protein structural mobility, thermodynamic stability, and catalysis. FEBS Lett. 2006;580:1685-90.

12. Hang HC, Bertozzi CR. Chemoselective approaches to glycoprotein assembly. Acc Chem Res. 2001;34:727-36.

13. Dwek RA. Glycobiology-more functions for oligosaccharides. Science. 1995;269:1234-5.

14. Solá R, Rodriguez-Martinez J, Griebenow K. Modulation of protein biophysical properties by chemical glycosylation: biochemical insights and biomedical implications. Cell Mol Life Sci. 2007;64:2133-52.

15. Sharma R, Chisti Y, Banerjee UC. Production, purification, characterization, and applications of lipases. Biotechnol Adv. 2001;19:627-62.

16. Soumanou MM, Pérignon M, Villeneuve P. Lipase-catalyzed interesterification reactions for human milk fat substitutes production: a review. Eur J Lipid Sci Technol. 2013;115:270-85.

17. Peng Q, Wang X, Shang M, Huang J, Guan G, Li Y, et al. Isolation of a novel alkaline-stable lipase from a metagenomic library and its specific application for milkfat flavor production. Microb Cell Fact. 2014;13:1-9.

18. Hama S, Kondo A. Enzymatic biodiesel production: an overview of potential feedstocks and process development. Bioresour Technol. 2013;135:386-95.

19. Mounguengui RWM, Brunschwig C, Baréa B, Villeneuve P, Blin J. Are plant lipases a promising alternative to catalyze transesterification for biodiesel production? Progr Energy Combust Sci. 2013;39:441-56.

20. Hwang HT, Qi F, Yuan C, Zhao X, Ramkrishna D, Liu D, et al. Lipase catalyzed process for biodiesel production: Protein engineering and lipase production. Biotechnol Bioeng. 2014;111:639-53.

21. Di Lorenzo M, Hidalgo A, Haas M, Bornscheuer UT. Heterologous production of functional forms of Rhizopus oryzae lipase in Escherichia coli. Appl Enviro Microbiol. 2005;71:8974-7.

22. Ueda M, Takahashi S, Washida M, Shiraga S, Tanaka A. Expression of Rhizopus oryzae lipase gene in Saccharomyces cerevisiae. J Mol Catal B-Enzym. 2002;17:113-24.

23. Takahashi S, Ueda M, Atomi H, Beer H, Bornscheuer U, Schmid R, et al. Extracellular production of active Rhizopus oryzae lipase by Saccharomyces cerevisiae. J Ferment Bioeng. 1998;86:164-8.

24. Resina D, Serrano A, Valero F, Ferrer P. Expression of a Rhizopus oryzae lipase in Pichia pastoris under control of the nitrogen source-regulated formaldehyde dehydrogenase promoter. J Biotechnol. 2004;109:103-13.

25. Minning S, Schmidt-Dannert C, Schmid R. Functional expression of Rhizopus oryzae lipase in Pichia pastoris: high-level production and some properties. J Biotechnol. 1998;66:147.

26. Minning S, Serrano A, Ferrer P, Sola C, Schmid RD, Valero F. Optimization of the high-level production of Rhizopus onyzae lipase in Pichia pastoris. J Biotechnol. 2001;86:59-70.

27. Liu Y, Xie W, Yu H. Enhanced activity of Rhizomucor miehei lipase by deglycosylation of its propeptide in Pichia pastoris. Curr Microbio. 2014;68:186-91.

28. Takahashi S, Ueda M, Tanaka A. Independent production of two molecular forms of a recombinant Rhizopus oryzae lipase by KEX2-engineered strains of Saccharomyces cerevisiae. Appl Microbiol Biotechnol. 1999;52:534-40.

29. Zhu J, Liu H, Zhang J, Wang P, Liu S, Liu G, et al. Effects of Asn-33 glycosylation on the thermostability of Thermomyces lanuginosus lipase. J Appl Microbiol. 2014;117:1-8.

30. Yu XW, Wang LL, Yan X. Rhizopus chinensis lipase: gene cloning, expression in Pichia pastoris and properties. J Mol Catal B-Enzym. 2009;57:304-11.

31. Yu XW, Sha C, Guo YL, Xiao R, Xu Y. High-level expression and characterization of a chimeric lipase from Rhizopus oryzae for biodiesel production. Biotechnol Biofuels. 2013;6:29.

32. Rudd PM, Scragg IG, Coghill E, Dwek RA. Separation and analysis of the glycoform populations of ribonuclease B using capillary electrophoresis. Glycoconjugate J. 1992;9:86-91.

33. Petrescu AJ, Milac AL, Petrescu SM, Dwek RA, Wormald MR. Statistical analysis of the protein environment of N-glycosylation sites: implications for occupancy, structure, and folding. Glycobiology. 2004;14:103-14.

34. Fryksdale BG, Jedrzejewski PT, Wong DL, Gaertner AL, Miller BS. Impact of deglycosylation methods on two-dimensional gel electrophoresis and matrix assisted laser desorption/ionization-time of flight-mass spectrometry for proteomic analysis. Electrophoresis. 2002;23:2184-93.

35. Maley F, Trimble RB, Tarentino AL, Plummer Jr TH. Characterization of glycoproteins and their associated oligosaccharides through the use of endoglycosidases. Anal Biochem. 1989;180:195-204. 
36. Durchschlag H, Christl R, Jaenicke R. Comparative determination of the particle weight of glycoproteins by SDS-PAGE and analytical ultracentrifugation. In Progress in Analytical Ultracentrifugation. Progr Colloid Polym Sci. 1991: 41-56

37. Brakch N, Allemandou F, Keller I, Nussberger J. The renin prosequence enhances constitutive secretion of renin and optimizes renin activity. Curr Neurovasc Res. 2011;8:121-30.

38. Han $M$, Wang $X$, Ding $H$, Jin $M, Y u L$, Wang J, et al. The role of $N$-glycosylation sites in the activity, stability, and expression of the recombinant elastase expressed by Pichia pastoris. Enzym Micro Technol. 2014;54:32-7.

39. Miller GC, Long CJ, Bojilova ED, Marchadier D, Badellino KO, Blanchard N, et al. Role of N-linked glycosylation in the secretion and activity of endothelial lipase. J Lipid Res. 2004;45:2080-7.

40. Desko MM, Gross DA, Kohler JJ. Effects of N-glycosylation on the activity and localization of GlcNAc-6-sulfotransferase 1. Glycobiology. 2009;19:1068-77.

41. Shinde $U$, Inouye M. Intramolecular chaperones and protein folding. Trends Biochem Sci. 1993;18:442-6.

42. Shinde U, Li Y, Chatterjee S, Inouye M. Folding pathway mediated by an intramolecular chaperone. Proc Natl Acad Sci U S A. 1993;90:6924-8.

43. Baker D, Sohl JL, Agard DA. A protein-folding reaction under kinetic control. Nature. 1992;356:263-5.

44. Mitra J, Tang X-j, Almo S, Shields D. Temperature-induced conformational changes in prosomatostatin-II: implications for processing. Biochem J. 1998;334:275-82.

45. Andersson E, Hellman L, Gullberg U, Olsson I. The role of the propeptide for processing and sorting of human myeloperoxidase. J Biolo Chemi. 1998;273:4747-53.

46. Imperiali B, O'Connor S. Effect of N-linked glycosylation on glycopeptide and glycoprotein structure. Curr Opin Chem Biol. 1999:3:643.

47. Muller-Steffner $\mathrm{H}$, Kuhn I, Argentini M, Schuber F. Identification of the $\mathrm{N}$-glycosylation sites on recombinant bovine CD38 expressed in Pichia pastoris: Their impact on enzyme stability and catalytic activity. Protein Expr Purif. 2010;70:151-7.

48. Mitsutaka Kohno ME, Rie T, Wataru K. Thermal stability of Rhizopus niveus lipase expressed in a Kex2 mutant yeast. J Biotechnol. 2000;81:141-50.

49. Fonseca-Maldonado R, Vieira DS, Alponti JS, Bonneil E, Thibault P, Ward RJ. Engineering the pattern of protein glycosylation modulates the thermostability of a GH11 xylanase. J Biolo Chemi. 2013:288:25522-34.

50. Rudd PM, Joao HC, Coghill E, Fiten P, Saunders MR, Opdenakker G, et al. Glycoforms modify the dynamic stability and functional activity of an enzyme. Biochem. 1994;33:17-22.

51. Lige $B, M a S$, van Huystee $R$. The effects of the site-directed removal of $\mathrm{N}$-glycosylation from cationic peanut peroxidase on its function. Arch Biochem Biophys. 2001;386:17-24.

52. Sugihara A, Ueshima M, Shimada Y, Tsunasawa S, Tominaga Y. Purification and characterization of a novel thermostable lipase from Pseudomonas cepacia. J Biochem. 1992;112:598-603.

53. Zou S, Huang S, Kaleem I, Li C. N-Glycosylation enhances functional and structural stability of recombinant $\beta$-glucuronidase expressed in Pichia pastoris. J Biotechnol. 2013;164:75-81.

54. Zhu SS, Yu XW, Xu Y. Constitutive expression of lipase in Pichia pastoris and the high throughput screening method. Microbiol China. 2012;39:873-81.

55. Hananan D. Studies on transformation of Escherichia coli with plasmids. J Mol Biol. 1983;166:557-80.

56. Kordel M, Hofmann B, Schomburg D, Schmid R. Extracellular lipase of Pseudomonas sp. strain ATCC 21808: purification, characterization, crystallization, and preliminary X-ray diffraction data. J Bacteriol. 1991;173:4836-41.

57. Laemmli UK. Cleavage of structural proteins during the assembly of the head of bacteriophage T4. Nature. 1970;227:680-5.

58. Burdette RA, Quinn D. Interfacial reaction dynamics and acyl-enzyme mechanism for lipoprotein lipase-catalyzed hydrolysis of lipid p-nitrophenyl esters. J Biolo Chemi. 1986;261:12016-21.

59. Hernández-Rodríguez B, Córdova J, Bárzana E, Favela-Torres E. Effects of organic solvents on activity and stability of lipases produced by thermotolerant fungi in solid-state fermentation. J Mol Catal B-Enzym. 2009;61:136-42.

\section{Submit your next manuscript to BioMed Central and take full advantage of:}

- Convenient online submission

- Thorough peer review

- No space constraints or color figure charges

- Immediate publication on acceptance

- Inclusion in PubMed, CAS, Scopus and Google Scholar

- Research which is freely available for redistribution

Submit your manuscript at www.biomedcentral.com/submit 